\title{
Tenaghi Philippon (Greece) Revisited: Drilling a Continuous Lower-Latitude Terrestrial Climate Archive of the Last 250,000 Years
}

\author{
by Jörg Pross, Polychronis Tzedakis, Gerhard Schmiedl, Kimon Christanis, \\ Henry Hooghiemstra, Ulrich C. Müller, Ulrich Kotthoff, \\ Stavros Kalaitzidis, and Alice Milner
}

doi:10.2204/iodp.sd.5.06.2007

\section{Introduction and Goals}

With the dramatically increasing manifestation of anthropogenic forcing on the Earth's climate, understanding the mechanisms and effects of abrupt climate change is crucial to extend the lead time for mitigation and adaptation. In this context, the climate variability during the Quaternary represents the closest analogy to present-day climate change. Unprecedented insights into both short-term (i.e., decadalto centennial-scale) and long-term (i.e., orbital-scale) climate variability over the last $740 \mathrm{kyr}$ have been derived from ice cores from polar regions (Dansgaard et al., 1993; EPICA community members, 2004). These records show that the higher latitudes repeatedly witnessed temperature changes of more than $10^{\circ} \mathrm{C}$ within human time scales (Severinghaus et al., 1998). Considerably less information is available on the characteristics of abrupt climate change in the middle and lower latitudes and on their imprint on terrestrial environments. These regions are, however, home to the majority of the Earth's population, and consequently they will witness the greatest impact of future climate change on people's lives.

Located in a strategic position between the higher-latitude (i.e., North Atlantic Oscillation-influenced) and lower-latitude (i.e., monsoonally-influenced) climate systems, the Mediterranean region is particularly sensitive in recording abrupt climate change and its imprint on terrestrial ecosystems. Moreover, terrestrial climate archives from the

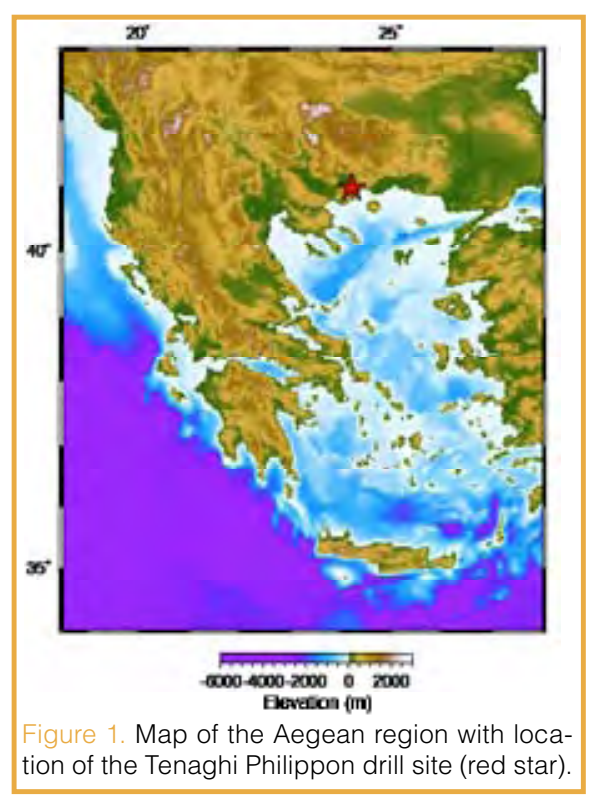

Mediterranean borderlands yield rich, diverse biotic signals also during colder intervals because the region's climate was relatively mild even underfully glacial boundary conditions. In contrast to higher-latitude records, this warrants the detailed analysis of shortterm climate variability in terres- trial environments throughout the full range of climatic boundary conditions of the Quaternary.

In light of the above, the climate archive of Tenaghi Philippon (site within the Drama Basin, Eastern Macedonia, Greece; Fig. 1) plays an exceptional role. Since the initiation of pollen-based vegetation analyses from drill cores in the late 1960s (Wijmstra, 1969), it has been increasingly recognized as one of the best terrestrial archives of Quaternary climate history in Europe. This prominent position is due to (1) its temporal length, spanning the last 1.35 million years and comprising at least nineteen consecutive glacial-interglacial cycles (Tzedakis et al., 2006); (2) its completeness, as evidenced by the close climato-stratigraphical correspondence with global deep-sea records; and (3) its proximal position with regard to glacial refugia of thermophilous plants in SE Europe, which reduces the time lag between atmospheric forcing and vegetation response as documented in pollen data.

Because previous investigations of the Tenaghi Philippon climate archive were restricted to a temporal resolution within the Milankovitch time band, and the core material used in these investigations has deteriorated, the potential of this site for the analysis of abrupt climate change has remained virtually untapped. Therefore, a campaign has been initiated to re-drill this archive; it is funded by the German Research Foundation, the Wilhelm Schuler Foundation, and the Royal Society (U.K.). The aim of this initiative is an interdisciplinary analysis of short-term climate variability under interglacial, "semi-glacial", and glacial boundary conditions of the Quaternary. Given the close proximity of the Tenaghi Philippon site to the Aegean Sea, special emphasis is placed on the identification of short-term environmental perturbations during intervals coeval with sapropelformation in the Eastern Mediterranean Sea. Disciplines include palynology, sedimentology, stable isotope geochemistry, coal petrology, photogrammetric and magnetic susceptibility core logging, magnetostratigraphy, and radiometric $\left({ }^{14} \mathrm{C},{ }^{40} \mathrm{Ar} /{ }^{39} \mathrm{Ar}\right)$ dating.

\section{Drilling at Tenaghi Philippon}

The Philippi peatland, which includes the Tenaghi Philippon site, is situated in the intramontane Drama Basin, Eastern Macedonia, Greece (Fig. 1). Owing to rapid subsidence that may have started in Late Miocene times, the 
Drama Basin constituted a limnic to telmatic setting throughout the Middle and Late Quaternary. Much of the basin fill that accumulated during this time consists of peat, resulting in the largest peat and lignite deposit of SE Europe. Based on the results of previous scientific drilling during the late 1960 s to mid-1970s, the sedimentary succession at Tenaghi Philippon is known to comprise peat, mud, lake marls, and clays until $198 \mathrm{~m}$ depth; further downhole, and until the maximum depth drilled $(280 \mathrm{~m})$, clastic input increases such that sediments are palynologically non-productive (Wijmstra and Smit, 1976a, b; Van der Wiel and Wijmstra, 1987).

A 60 -m-long core from Tenaghi Philippon $\left(40^{\circ} 58.40^{\prime} \mathrm{N}\right.$, $24^{\circ} 13.42$ 'E; $40 \mathrm{~m}$ above sea level) was drilled over three weeks in April 2005 using a WIRTH Eco1 drilling rig (Fig. 2) and a special, non-rotating probe driven by a pneumatic hammer system ("Dystel hammer"). The core, which has excellent recovery (97.8\%), is now stored in the core repository of the Institute of Geosciences, University of Tübingen, Germany. Magnetic susceptibility measurements were performed on the entire core. After splitting the core into an archive half and a working half, it was photogrammetrically scanned and lithologically described. To facilitate nondestructive magnetostratigraphic measurements (e.g., to identify the Blake and Lachamps reverse-polarity events), core segments that may comprise these events according to the preliminary age model (see below) have been left intact.

\section{Initial Results}

A first, preliminary age model for the entire core has been established based on the analysis of pollen samples from the bottom of each 1-m-long core segment. The overview record presented in Fig. 3 indicates a succession of pollen zones reflecting open, steppe-like vegetation intercalated with zones reflecting the prevalence of Mediterranean forests (Fig. 4). Figure 3 also shows a preliminary correlation with the SPECMAP chronology (Imbrie et al., 1984) and insolation values (Berger and Loutre, 1991). We interpret the interval from $0 \mathrm{~m}$ to $5 \mathrm{~m}$ to represent the Holocene and Late Glacial, with Late Glacial climate fluctuations being yet unresolved because of low resolution. The interval from $5 \mathrm{~m}$ to $19 \mathrm{~m}$ is approximately correlative to Marine Isotope Stages (MIS) 2 to 4 . The intervals from $19 \mathrm{~m}$ to $34 \mathrm{~m}$ and $34 \mathrm{~m}$ to $42 \mathrm{~m}$ represent MIS 5 and MIS 6, respectively. The stratigraphic interpretation below $42 \mathrm{~m}$ is less straightforward due to the low-resolution age model available at present. According to our current interpretation, the interval from $42 \mathrm{~m}$ to $57 \mathrm{~m}$ correlates with MIS 7, and the

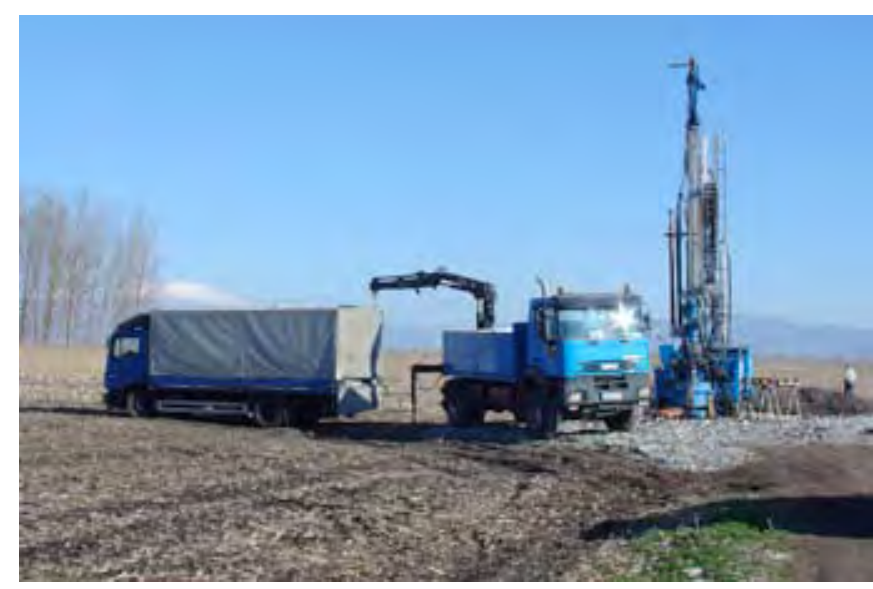

Drilling rig WIRTH Eco1 used for drilling in the Drama Basin. The Phalakron mountain range (2232 $\mathrm{m}$ a.s.I.), which borders the Drama Basin to the northeast, is visible in the background.

interval down-core corresponds to MIS 8. Although absolute age control is not yet available, our data indicate that the core comprises at least the last $250 \mathrm{kyr}$, potentially even the last $290 \mathrm{kyr}$.

Tephra layers in the core, which have the potential for ${ }^{40} \mathrm{Ar} /{ }^{39} \mathrm{Ar}$ dating, provide a unique opportunity for age control independent from both palyno-stratigraphic and radiocarbon dating. Moreover, they allow the direct correlation with other terrestrial and marine climate archives from the Eastern Mediterranean region. As depicted in Fig. 3, the magnetic susceptibility curve exhibits prominent spikes that point to the positions of tephra layers. The inspection of layers with high magnetic susceptibility within the already split part of the core resulted in the identification of tephra layers with glass and pumice shards. The layer at $7.59 \mathrm{~m}$ represents the PhT2 tephra derived from the Cape Riva eruption of Santorini at $\sim 22 \mathrm{kyr}$ BP and correlates with Y-2 in the Mediterranean Sea. The PhT3 tephra at $12.80 \mathrm{~m}$ is

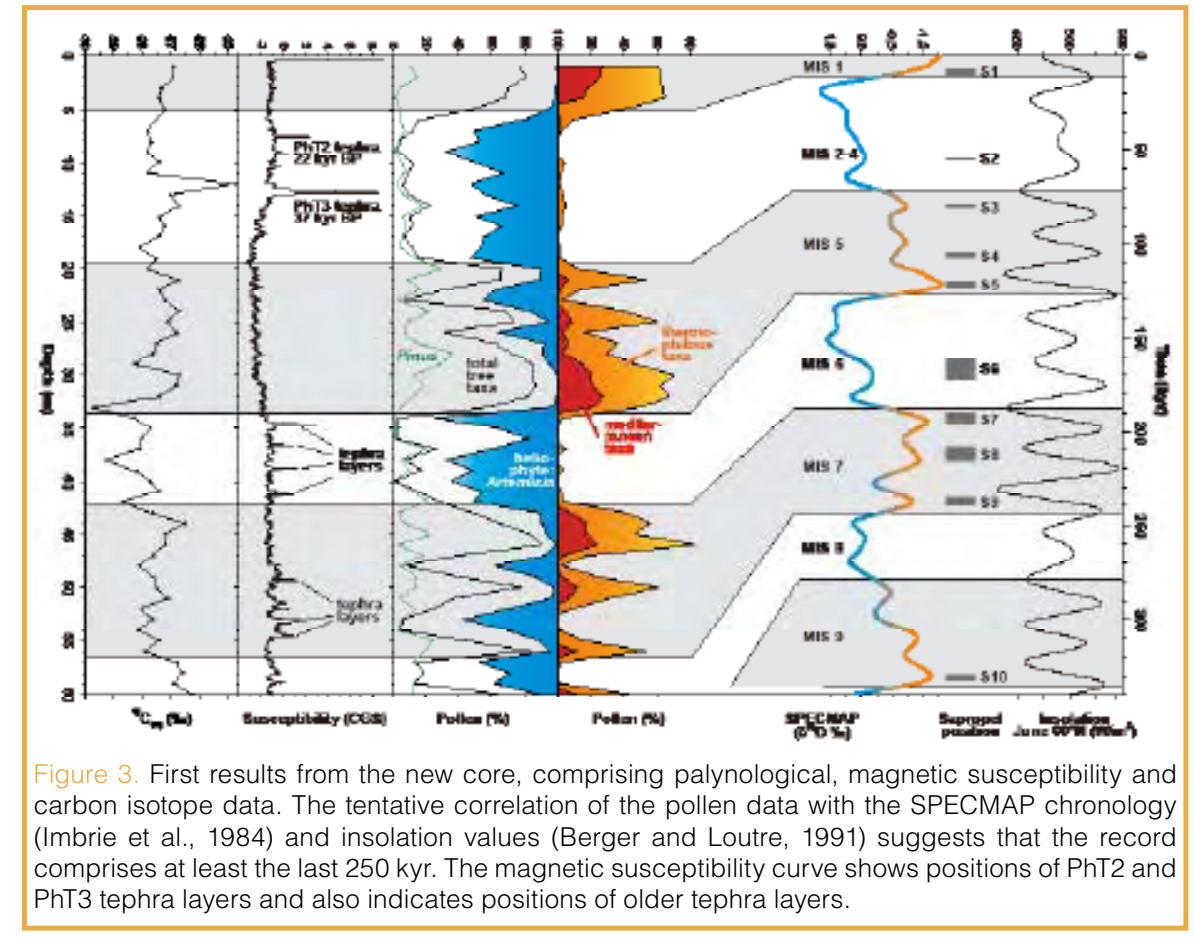




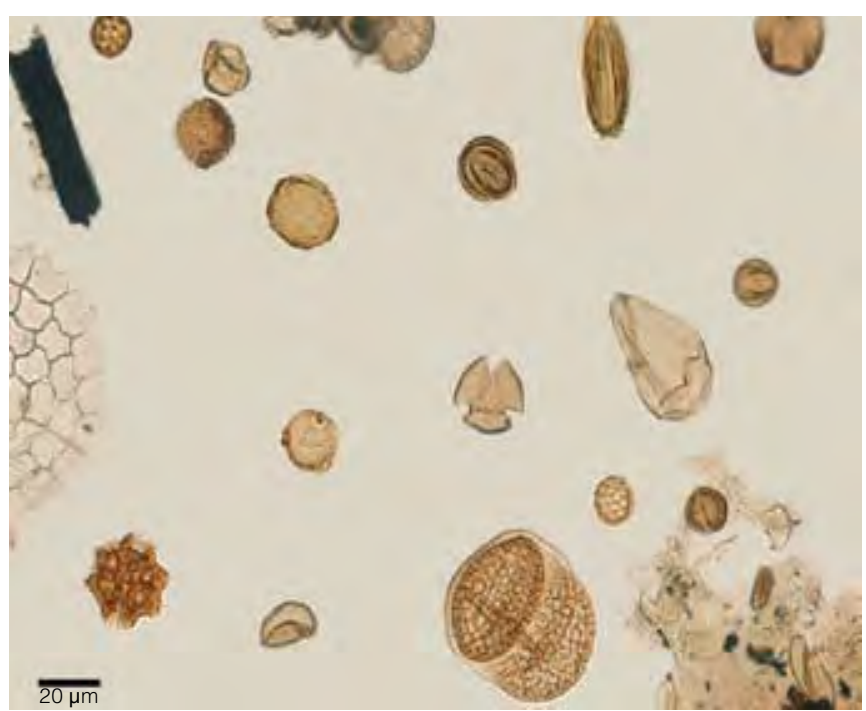

Figure 4. Typical glacial pollen spectrum from the new core (Sample is from a core depth of $10.0 \mathrm{~m}$, corresponding to Marine Isotope Stage 3).

correlative to the Campanian Ignimbrite and Y-5 in the Mediterranean Sea, having a ${ }^{40} \mathrm{Ar} /{ }^{39} \mathrm{Ar}$ age of $\sim 37 \mathrm{kyr} \mathrm{BP}$ (S. Wulf, 2006, pers. comm.).

High resolution studies of the core are currently underway, including palynology and sedimentology (Frankfurt, Leeds), stable isotope geochemistry, radiocarbon and tephra dating (Frankfurt), and coal petrology (Patras). The analytical phase of this multi-disciplinary project is scheduled for the next three years. Following the compilation of data by each group/discipline, a synthesis study is planned for the final phase of the project. The integration of the resulting data will allow new insights into the characteristics of abrupt (decadalto centennial-scale) climatic change and their consequences for terrestrial environments in the Mediterranean region.

\section{Acknowledgements}

Theodoros Kalliontzis, Andreas Balikas, Constantinos Tsompanoglou, and Nikos Nikolaidis provided invaluable support during field work. Ferdinand Stölben and his team (www.stoelbenbohr.de) did an excellent job in recovering high quality core material. Funding by the German Research Foundation (project $\operatorname{Pr} 651 / 3$ ), the Wilhelm Schuler Foundation, and The Royal Society (United Kingdom) is gratefully acknowledged.

\section{References}

Berger, A.L., and Loutre, M.F., 1991. Insolation values for the climate of the last 10 million years. Quat. Sci. Rev., 10:297-317, doi:10.1016/0277-3791(91)90033-Q.

Dansgaard, W., Johnsen, S.J., Clausen, H.B., Dahljensen, D., Gundestrup, N.S., Hammer, C.U., Hvidberg, C.S., Steffensen, J.P., Sveinbjornsdottir, A.E., Jouzel, J., and Bond, G., 1993. Evidence for general instability of past climate from a 250kyr ice-core record. Nature, 364:218-220, doi:10.1038/ $364218 \mathrm{a} 0$.

EPICA community members, 2004. Eight glacial cycles from an Antarctic ice core. Nature, 429:623-628.
Imbrie, J., Hays, J.D., Martinson, D.G., McIntyre, A., and Mix, A.C., 1984. The orbital theory of Pleistocene climate: support from a revised chronology of the marine $\delta 18 \mathrm{O}$ record. In Berger, A.L., Imbrie, J., Hays, J., Kukla, G., and Saltzman, B. (Eds.), Milankovitch and Climate Part I. Dordrecht, The Netherlands (Kluwer), 269-305.

IOC, IHO, and BODC, 2003. General Bathymetric Chart of the Oceans. Centenary edition of the GEBCO Digital Atlas. CD-ROM. The Intergovernmental Oceanographic Commission and the International Hydrographic Organization, as part of the. British Oceanographic Data Centre (Liverpool, U.K). http://www.bodc.ac.uk/products/bodc_products/gebco/

Severinghaus, J.P., Sowers, T., Brook, E.J., Alley, R.B., and Bender, M.L., 1998. Timing of abrupt climate change at the end of the Younger Dryas interval from thermally fractionated gases in polar ice. Nature, 391:141-146, doi:10.1038/34346.

Tzedakis, P.C., Hooghiemstra, H., and Pälike, H., 2006. The last 1.35 million years at Tenaghi Philippon: revised chronostratigraphy and long-term vegetation trends. Quat. Sci. Rev., 25:3416-3430, doi:10.1016/j.quascirev.2006.09.002.

Van der Wiel, A.M., and Wijmstra, T.A., 1987a. Palynology of the lower part (78-120 m) of the core Tenaghi Philippon II, Middle Pleistocene of Macedonia, Greece. Rev. Palaeobot. Palynol., 52:73-88, doi:10.1016/0034-6667(87)90047-9.

Van der Wiel, A.M., and Wijmstra, T.A., 1987b. Palynology of the 112.8-197.8 m interval of the core Tenaghi Philippon III, Middle Pleistocene of Macedonia, Greece. Rev. Palaeobot. Palynol., 52:89-117, doi:10.1016/0034-6667(87)90048-0.

Wijmstra, T.A., 1969. Palynology of the first $30 \mathrm{~m}$ of a $120 \mathrm{~m}$ deep section in northern Greece. Acta Bot. Neerland., 18:511-527.

Wijmstra, T.A., and Smit, A., 1976. Palynology of the middle part (30-78 meters) of a $120 \mathrm{~m}$ deep section in northern Greece (Macedonia). Acta Bot. Neerland., 25:297-312.

\section{Authors}

Jörg Pross, Ulrich C. Müller, Ulrich Kotthoff, Institute of Geosciences, University of Frankfurt, Altenhöfer Allee 1, D-60438 Frankfurt, Germany, e-mail: joerg.pross@em.unifrankfurt.de.

Polychronis Tzedakis, Alice Milner, School of Geography, University of Leeds, West Yorkshire LS2 9JT, U.K.

Gerhard Schmiedl, Geological-Paleontological Institute, University of Hamburg, Bundesstraße 55, D-20146 Hamburg, Germany.

Kimon Christanis, Stavros Kalaitzidis, Department of Geology, University of Patras, GR-265.00 Rio-Patras, Greece.

Henry Hooghiemstra, Institute for Biodiversity and Ecosystem Dynamics, University of Amsterdam, Kruislaan 318, NL-1098 SM Amsterdam, The Netherlands.

\section{Related Web Link}

www.stoelbenbohr.de

\section{Photo and Figure Credits}

Fig. 1. Bathymetry and elevation taken from the GEBCO digital atlas (IOC, IHO, and BODC, 2003).

Fig. 2. Photo by Ulrich C. Müller.

Fig. 4. Photo by Ulrich Kotthoff. 